\title{
Milk yield and composition in dairy cows fed a diet with evening primrose (Oenothera paradoxa) full fat seeds or oil cake
}

\author{
J.A. Strzetelski ${ }^{1}$, J. Kowalczyk ${ }^{2}$, Teofila Stasiniewicz', \\ Elżbieta Lipiarska', S. Osięglowski' ${ }^{1}$ and K. Bilik' \\ 'Research Institute' of Animal Production, \\ Department of Animal Physiology and Nutrition \\ 32-083 Balice, Poland \\ ${ }^{2}$ The Kielanowski Institute of Animal Physiology and Nutrition, \\ Polish Academy of Sciences \\ 05-110 Jablonna, Poland
}

(Received 16 November 1998; accepted 19 November 1998)

\begin{abstract}
The experiment was carried out on 30 Black-and-White Lowland dairy cows divided into 3 groups of 10 to investigate the effect of feeding evening primrose (Oenothera paradoxa) full fat seeds or oil cake on milk yield and composition. The animals were fed a basic ration consisting of maize silage, sugar beet top silage, meadow hay or green pasture forage (in summer) and concentrate mixture (control group - C) supplemented with evening primrose oil cake (group - O) or full fat seeds (group - S) from the beginning to I00th day of lactation. Average daily milk production was $31.4,32.1$ and $33.2 \mathrm{~kg}$ in the $\mathrm{C}, \mathrm{S}$ and $\mathrm{O}$ groups, respectively, but differences between the groups were statistically insignificant. The fat content in milk from cows receiving oil cake $(3.88 \%)$ or full fat seeds $(3.93 \%)$ with their ration tended to be higher than in the control group $(3.78 \%)$ but the level of protein and lactose in milk was similar in all groups.
\end{abstract}

KEY WORDS: evening primrose, full fat seeds, oil cake, dairy cow, milk

\section{INTRODUCTION}

Evening primrose (Oenothera paradoxa) seed fat contains a high level of unsaturated fatty acids, particularly of $\gamma$-linolenic acid which is essential for animals. A deficiency of this acid causes disorders in some metabolic pathways (Hudson, 1984; Horrobin, 1990; Lammer-Zarawska, 1992) which could negatively affect animal production and feed efficiency. 
Previous studies on the nutritive value and effect of feeding evening primrose oil cake as a diet component on beef quality, milk composition, calf performance and nutrient digestibility and utilisation have already been published (Stasiniewicz et al., 1998; Strzetelski et al., 1998 a, b,c).

The aim of the experiment was to compare milk yield and composition from cows fed diet supplemented with full fat evening primrose seeds or oil cake.

\section{MATERIAL AND METHODS}

\section{Animals and feeding}

An experiment was carried out on 30 Black-and-White Lowland cows of average body weight $650 \pm 50 \mathrm{~kg}$, divided into 3 groups of 10 according to an analogue method based on HF blood share (av. $58 \%$ ), lactation rank (2-5) and milk yield at the peak of last lactation. Groups of animals were completed successively at 3 weeks before calving over a period of three months. The experiment lasted from calving to day 100 of lactation. Daily milk production of each cow and content of fat, protein and lactose in samples representing 3-day periods during the whole experiment were determined.

All animals were individually fed a basic ration consisting of maize silage and sugar beet tops silage (70:30\% in DM, respectively), meadow hay or green pasture forage (in summer) and concentrate mixture (control group - C), supplemented with $10 \%$ evening primrose oil cake (group - $\mathrm{O}$ ) or with the addition of full fat seeds $-350 \mathrm{~g} /$ day $/$ cow (group $-\mathrm{S}$ ) from the beginning to day 100 of lactation (Table 1).

TABLE 1

Composition of concentrate mixtures, $\%$

\begin{tabular}{lcc}
\hline Item & $\mathrm{C}$ and S & $\mathrm{O}$ \\
\hline Barley, ground & 3.0 & 2.0 \\
Wheat bran & 1.0 & 1.0 \\
Soyabean oilmeal & 14.0 & 10.0 \\
Triticale, ground & 69.0 & 68.0 \\
Meat-and-bone meal & 4.0 & 4.0 \\
Dehydrated whole barley crop with undersown lucerne & 5.0 & 1.0 \\
Evening primrose oil cakc & - & 10.0 \\
Mineral mixture' & 4.0 & 4.0 \\
\hline
\end{tabular}

' composition, \%: $12.5 \mathrm{CaHPO}_{4}, 12.5$ limestone, 12.5 premix B, 62.5 commercial mineral mixture MMB

in $\mathrm{kg}, \mathrm{g}: \mathrm{Ca}-184.2, \mathrm{P}-120.6, \mathrm{Na}-31.2, \mathrm{Cl}-47.5, \mathrm{Mg}-28.7$ mg: $\mathrm{Mn}-469, \mathrm{Zn}-3375, \mathrm{Cu}-956, \mathrm{Co}-17.5, \mathrm{~J}-17.5$ 
Feed intake was controlled. Cows were fed according to the INRA system (IZ-INRA, 1993). Proximate chemical analysis of feeds was carried out according to AOAC (1990) methods. Fat, protein and lactose in milk were determined with Milko-Scan 133B equipment. The nutritive value of feeds, concentrate mixtures and daily rations were set up using INWAR ver. 1.0 and INRAtion ver. 2.6 (1994) software systems.

The results were subjected to statistical analysis using one-way analysis of variance estimating the significance of differences between groups with multiple interval test according to Statgraphics Plus 6.0 (1992) software.

\section{RESULTS}

Concentrate mixtures contained about $17 \%$ crude protein, but there was about $40 \%$ less fat in the concentrate mixture for the control group than in the concentrate with evening primrose oil cake (Table 2). Average daily intake of nutrients was similar in all groups. Daily intake of DM was $18.6 \pm 0.4 \mathrm{~kg}$, crude protein

TABLE 2

Chemical composition and nutritive value of feeds

\begin{tabular}{|c|c|c|c|c|c|c|c|c|}
\hline \multirow{3}{*}{ Feed } & \multicolumn{5}{|c|}{ Chemical composition, $\%$} & \multicolumn{3}{|c|}{ In l k of dry matter, INRA system } \\
\hline & \multirow{2}{*}{$\begin{array}{c}\text { dry } \\
\text { matter }\end{array}$} & \multirow{2}{*}{$\begin{array}{c}\text { crude } \\
\text { proteine }\end{array}$} & \multirow{2}{*}{$\begin{array}{l}\text { ether } \\
\text { extract }\end{array}$} & \multirow{2}{*}{$\begin{array}{l}\text { crude } \\
\text { fibre }\end{array}$} & \multirow[t]{2}{*}{ ash } & \multirow[t]{2}{*}{ UFL } & \multicolumn{2}{|c|}{ PDI, g } \\
\hline & & & & & & & PDIN & PDIE \\
\hline Barley, ground & 87.72 & 10.58 & 2.45 & 4.49 & 2.19 & 1.19 & 79 & 102 \\
\hline Wheat bran & 87.12 & 14.36 & 3.57 & 7.14 & 3.59 & 0.94 & 109 & 96 \\
\hline Soyabean oilmeal & 88.79 & 43.43 & 1.65 & 6.50 & 5.99 & 1.21 & 348 & 244 \\
\hline Triticale, ground & 87.21 & 11.36 & 1.77 & 3.01 & 1.86 & 1.24 & 88 & 108 \\
\hline Meat-and-bone meal & 93.62 & 56.13 & 12.84 & 3.59 & 15.39 & 1.16 & 420 & 292 \\
\hline $\begin{array}{l}\text { Dehydrated whole barley } \\
\text { crop with undersow! }\end{array}$ & & & & & & & & \\
\hline lucerne & 91.20 & 14.91 & 2.60 & 27.75 & 8.00 & 0.59 & 103 & 88 \\
\hline $\begin{array}{l}\text { Evening primrose oil } \\
\text { cake }\end{array}$ & 89.79 & 21.01 & 12.00 & 21.42 & 7.95 & 0.60 & 151 & 125 \\
\hline $\begin{array}{l}\text { Seeds of evening } \\
\text { primrose }\end{array}$ & & & & & & & & \\
\hline Maize silage & 26.20 & 2.46 & 1.40 & 5.76 & 1.69 & 0.88 & 58 & 68 \\
\hline Beet-top silage & 18.37 & 3.02 & 1.10 & 3.31 & 4.74 & 0.60 & 100 & 79 \\
\hline Meadow hay & 88.27 & 10.57 & 2.47 & 27.78 & 5.61 & 0.73 & 75 & 79 \\
\hline Green forage & 21.37 & 3.26 & 0.79 & 5.19 & 1.74 & 0.96 & 96 & 93 \\
\hline Concentrate mixture $\mathrm{C}$ & 87.90 & 17.40 & 2.07 & 4.83 & 6.68 & 1.15 & 135 & 130 \\
\hline Concentrate mixture $\mathrm{O}$ & 87.90 & 16.96 & 3.30 & 5.45 & 6.94 & 1.16 & 131 & 127 \\
\hline
\end{tabular}

IZ - INRA (1993): UFL - unit for milk production; PDI - protein truly digestible in the small intestine: PDIN - PDI dependent on $\mathrm{NH}_{3}-\mathrm{N}$ amount: PDIE-PDI dependent on energy amount 
$2870 \pm 40 \mathrm{~g}, 1850 \mathrm{~g}$ PDI (PDIE - PDIN $=-37 \mathrm{~g}$ ) and about $16.3 \mathrm{UFL}$. Average intake of evening primrose oil cake in group $\mathrm{O}$ was $764 \mathrm{~g}$ containing $92 \mathrm{~g}$ of oil, whereas cows of group $\mathrm{S}$ received $350 \mathrm{~g}$ full fat seeds containing $84 \mathrm{~g}$ of oil.

Daily milk production and composition did not differ significantly between the groups, however, there was a tendency to higher milk yield in cows receiving evening primrose oil cake (by $5.7 \%$ ) and full fat seeds (by $2.2 \%$ ) than in control animals. A similar tendency was observed in the level of fat in milk of respective groups of animals, but the protein and lactose concentrations were similar in milk of all animals. Feed efficiency was slightly better, but not significantly, in animals of group $\mathrm{O}$ (Table 3).

TABLE 3

Yicld, composition of milk and utilisation of nutrients

\begin{tabular}{lrrrr}
\hline Itcm & \multicolumn{3}{c}{ Groups } & \\
\cline { 2 - 4 } & \multicolumn{1}{c}{$\mathrm{C}$} & $\mathrm{O}$ & $\mathrm{S}$ & $\mathrm{SE}$ \\
\hline Milk yield, kg/day & & & & \\
$\quad$ initial (mean of initial 7 days of lactation) & 20.21 & 20.85 & 20.07 & 4.67 \\
final (mean of final 7 days of lactation) & 27.20 & 28.57 & 27.41 & 4.19 \\
mean & 31.40 & 33.20 & 32.09 & 3.76 \\
FCM, kg & 30.36 & 32.60 & 31.75 & 3.38 \\
milk fat, \% & 3.78 & 3.88 & 3.93 & 0.28 \\
milk protein, \% & 3.02 & 3.03 & 3.04 & 0.10 \\
lactose, \% & 4.69 & 4.65 & 4.59 & 0.12 \\
Utilisation of nutrients, per 1 k of milk & & & & \\
dry matter, kg & & & & \\
crude protein, g & 0.59 & 0.57 & 0.59 & 0.07 \\
PDI, g & 90.99 & 85.44 & 90.58 & 10.29 \\
$\quad$ NE (UFL) & 59.13 & 55.28 & 59.81 & 7.01 \\
\hline
\end{tabular}

\section{DISCUSSION}

Slightly higher milk yield in cows receiving the diet with evening primrose oil cake or full fat seeds in comparison with control animals suggests a stimulating influence of these feeds on milk production. The reason for that could be the high proportion of biologically active $\gamma$-linolenic acid in evening primrose oil (Lammer-Zarawska, 1992) as metabolites of this acid affect tissue metabolism (Horrobin, 1990) and thereby could have a beneficial influence on animal production.

The advantageous tendency of supplementing diets for dairy cows with oil plant seeds to increase the level of milk fat has been reported, similarly as in the present experiment, by others (Palmquist, 1984; Murphy et al., 1990).

It is difficult to explain the lack of differences between groups in the level of protein in milk, as usually increased fat levels in the diet are associated with a 
decrease in the protein content in milk (Palmquist and Moser, 1981; Driver et al., 1990; Murphy et al., 1990). However, in the cited experiments the level of fat in diets was higher than in the present study. It is possible that the amount of fat introduced into diets $\mathrm{O}$ and $\mathrm{S}$ was too low to affect the hormonal status of cows and thereby amino acid transport and utilisation in the mammary gland (Palmquist and Moser 1981; Casper and Schingoethe, 1989). There is rather a small chance that the fat of evening primrose oil cake or full fat seeds inhibited microbial protein synthesis in the rumen, as the contribution of this fat in the diet was low. Hanczakowski and Szymczyk (1993) reported that evening primrose seeds and oil cake contain relatively high levels of tannins forming complexes with protein. Such complexes are poorly degraded in the rumen and protect fat from rapid release, saponification, biohydrogenation and conversion into the trans isomeric form of unsaturated fatty acids (Strzetelski et al., 1987). Having this in mind there is no reason to suppose that cellulolytic activity in the rumen was reduced by transacids, all the more so as the composition of concentrate mixtures fed to animals indicates that the content of PDIE and PDIN was similar in all mixtures.

\section{CONCLUSIONS}

In conclusion of this study it could be stated that both evening primrose full fat seeds and oil cake can be fed to lactating cows, increasing to some extent milk yield, and can also be considered a biologically active additive.

\section{REFERENCES}

AOAC, 1990. Association of Official Analytical Chemists, Official Methods of Analysis. 15 th Edition. Arlington, VA

Casper D.P., Schingoethe D.J., 1989. Model to describe an alleviate milk protein depression in early lactation dairy cows fed a high fat diet. J. Dairy Sci. 72, 3327-3335

Driver L.S., Grummer M.M., Schultz L.H., 1990. Effect of heat-treated soya beans and niacin to high producing cows in early lactation. J. Dairy Sci. 73, 463-469

Hanczakowski P., Szymczyk B., 1993. The nutritive value of the residues remaining after oil extraction from seeds of evening primrose (Oenothera biennis L.). J. Sci. Food Agric. 63, 375-375

Horrobin D.F., 1990. $\gamma$-linolenic acid: an intermediate in essential fatty acid metabolism, with potential as an ethical pharmaceutical and as a food. Rev. Contemp. Pharmacother. 1, 1-45

Hudson B.I.F., 1984. Evening primrose (Oenothera spp.) oil and seed. J. Amer. Chem. Soc. 61, 540-543

IZ, 1993. Research Institute of Animal Production. Standards for Cattle, Sheep and Goat Nutrition (in Polish). Omnitech Press, Warszawa (Poland)

Lammer-Zarawska E., 1992. Biological properties of evening primrose oil (Oleum oenothera) (in Polish). In: Proceedings of Symposium: Evening Primrose Oil in Prophylaxis and Therapy. Łódź (Poland), pp. 40-44 
Murphy J.J., McNell G.P., Connolly J.F., Glesson P.A., 1990. Effect on cow performance and milk fat composition of including of full fat soya bean and rape seed in the concentrate mixture for lactating dairy cows. J. Dairy Res. 57, 295-306

Palmquist D.L., 1984. Use of fats in diets for lactating dairy cows. In: J. Wiseman (Editor). Fats in Animal Nutrition. Butterworths, London, pp. 353-387

Palmquist D.I., Moser E., 1981. Dietary fat effects on blood insuline, glucose utilisation and milk protein content of lactating cows. J. Dairy Sci. 64, 1664-1670

Stasiniewicz T., Niwińska B., Strzetelski J.A., Kowalczyk J., Maciaszek K., Bilik K., 1998. Nutritive value of evening primrose (Oenothera paradoxa) cake for ruminants. J. Anim. Feed Sci. 7, 187-195

Strzetelski J.A., Kowalczyk J., Krawczyk K., Stasiniewicz T., Lipiarska E., 1998a. Evening primrose (Oenothera paradoxa) oil cake or ground rape seed supplement to diets for dairy cows. J. Anim. Feed Sci., 7, 365-375

Strzetelski J.A., Kowalczyk J., Niwińska K., Krawczyk K., Maciaszek K., 1998b. A note of rearing calves on diet supplemented with evening primrose (Oenothera paradoxa) oil cake. J. Anim. Feed Sci. 7, 377-383

Strzetelski J.A., Krawczyk K., Kowalczyk J., Stasinicwicz T., Osięgłowski S., Lipiarska E., 1998c. Performance and body fat composition of fattening bulls fed diets with evening primrose (Oenothera paradoxa) oil cake. J. Anim. Feed Sci. 7, 261-271

Strzetelski J.A., Ryś R., Stasiniewicz T., Sroka M., Tarnowska K., Marek B., 1987. Effect of formaldehyde-treated protein in the seeds of protein-rich oil plants on the resistance of fat to hydrogenation in the rumen on the content of milk fat and its unsaturated fatty acids in dairy cows (in Polish). Acta Agr. Silv., Ser. Zoot. 26, 187-200

\section{STRESZCZENIE}

\section{Nasiona i makuch z wiesiolka jako czynniki stymulujące produkcyjność i wplywające na skład mleka krów}

Trzydzieści krów rasy nizinno czarno-białej podzielono na 3 grupy po 10 i żywiono przez 100 dni od początku laktacji dawką podstawową złożoną z kiszonki z kukurydzy i kiszonki z liści buraków cukrowych, siana łąkowego lub zielonki pastwiskowej (w sezonie letnim) oraz mieszanką treściwą z dodatkiem poekstrakcyjnej śruty sojowej (grupa kontrolna C), makuchu z wiesiołka (grupa O) lub pełnothustych nasion wiesiołka (grupa S). Średnia dzienna wydajność mleka wynosiła 31,4; 33,2 i $32,1 \mathrm{~kg}$ odpowiednio w grupach C, O i S. Krowy produkowały więcej o 2,24 kg FCM w grupic O i o l,4 kg FCM w grupic S niż w grupic kontrolnej, lecz różnice te nie były statystycznie istotne. Mleko od krów z grupy doświadczalnej $\mathrm{O}$ zawierało 3,88\%, z grupy $\mathrm{S}-3,93 \%$ tłuszczu, podczas gdy z grupy kontrolnej - 3,78\% (różnice nieistotne). Zawartość białka i laktozy w mleku była podobna we wszystkich grupach. 